\title{
EduMedia
}

\section{- produktion af multimediepræsentationer via Internettet}

\author{
Diba Terese Markus \\ Cand. mag. i multimedier \\ Naturvidenskabeligt IT Kompetencecenter (NIK) \\ Københavns Universitet \\ dtmarkus@nik.ku.dk \\ http://www.nik.ku.dk
}

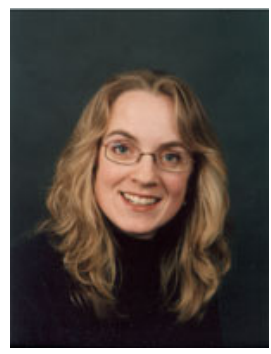

Diba Terese Markus arbejder med e-læring ved det Naturvidenskabelige Fakultet på Københavns Universitet. Her fungerer hun som sparringspartner på det pæedagogiske, didaktiske og tekniske område for undervisere, der ønsker at integrere informations- og kommunikationsteknologi i deres undervisning. Herudover arbejder hun med udvikling og implementering af internetbaserede vcrktøjer til undervisningsbrug.

\section{Baggrund}

Forelæsningen spiller traditionelt en vigtig rolle i undervisningen på universiteterne. Gennem århundreder har forelæsningen som grundform været uændret, selv om tekniske hjælpemidler som Powerpoint-præsentationer er taget i brug i de senere år, og skønt det bliver stadig mere udbredt at optage forelæsninger for at kunne tilbyde dem over Internettet.

Den stigende vægt på fleksibel læring, på transformationen fra passiv tilegnelse til aktiv læring, og ønsket om effektiv anvendelse af IT og nye medier i undervisningen gør det imidlertid nødvendigt at redefinere forelæsningen som undervisningsform. Det er i dag teknisk muligt at videreudvikle den IT-støttede forelæsning til en interaktiv, web-baseret multimediepræsentation - et koncept der er under udvikling.

På NIK (Naturvidenskabeligt IT Kompetencecenter) ved Københavns Universitet har vi startet EduMedia-projektet for dels at udforske de nye muligheder, dels at stille et redskab til rådighed for undervisere, der gør det muligt for dem at producere multimediepræsentationer til deres undervisning over Internettet.

\section{Forelæsninger vs. distribuerede læringsressourcer}

Forelæsningen må siges at være et særdeles "holdbart” koncept indenfor universitetsundervisning. Holdbart i betydningen "gennemprøvet og ekstensivt brugt" - ikke nødvendigvis "pædagogisk hensigtsmæssig”. Ulemperne er velkendte; f.eks. at det er vanskeligt for underviseren at etablere en dialog omkring stoffet - noget det i øvrigt også kan være svært at frigøre tid til - ligesom det er vanskeligt at fastholde interessen hos de studerende, der er henvist til at forholde sig passive. For de studerende er det umuligt at fastholde det kommunikerede i erindringen (man kan så argumentere, at det heller ikke er formålet med en forelæsning). Endelig, ja, så skal man jo være der. Med andre ord, så lever de færreste forelæsninger op til idealerne om fleksibilitet i forhold til tid, sted, læringsstil og tempo (Collis 2001).

Gennem tiden er forelæsningen som koncept da også blevet udviklet over flere omgange: Først med udbredelsen af overheads, der fik sin afløser i de teknisk mere raffinerede slide shows, som i dag kan være rene multimedia-shows. En videreudvikling er "videoforelcesninger", distribueret synkront eller asynkront over Internettet i et forsøg på at tilgodese ønsket om en fleksibel læring. 
I første nummer af dette tidsskrift identificerede Bo Fibiger tre genrer indenfor videobaserede læringsressourcer (Fibiger, 2003). Det kan være nyttigt at tage udgangspunkt i denne genreinddeling for at have en fælles forståelse af udfordringen i at udvikle forelæsningen som form via dagens teknologiske muligheder.

Den simpleste type videobaserede læringsressource, som blot består i optagelser af forelæsere, har efterhånden eksisteret i mange år. Ressourcer af den type fungerer blot som dokumentation af afholdte aktiviteter. Deres væsentligste berettigelse består i, at de giver den studerende mulighed for at følge undervisningen uafhængigt af tid og/eller sted, men interaktionsmulighederne er absolut minimale.

Den anden genre indenfor videobaserede læringsressourcer, som også har eksisteret i nogle år, er den distribuerede videoforelcesninger videooptagelsen synkroniseret med mediaelementer som slideshows og ofte kombineret med en slideoversigt/indholdsfortegnelse, der tillader en vis interaktivitet i form af navigation i forelæsningen.

Den tredje og sidste genre, den distribuerede læringsressource, er et koncept under udvikling. Fælles for forsøgene med denne type læringsressource er, at den skal være andet og mere end en distribueret forelæsning: Den skal støtte de studerende i deres eget arbejde med et givent stof. Ingen ved præcis hvordan dét skal gøres, og der er klart mange problemer i at ville indfri denne ambition (Hornbæk et al. 2002). Der er mange bud på, hvordan en sådan læringsressource kan bringes til at understøtte læringen, som f.eks. gennem forbedrede muligheder i forhold til at browse i video, en omfattende linkstruktur til supplerende materiale såsom tekst, grafik, animationer, simuleringer mv., muligheder for at foretage annotationer, indgå i diskussionsfora mv. (f.eks. Bargeon et al. 2002, Fibiger 2003, Haga 2002, Hornbæk et al. 2002).

Intentionen med udviklingen af EduMedia er at stille en platform til rådighed, der sætter undervisere i stand til at fremstille multimedieprcesentationer, der kan bruges som distribuerede læringsressourcer. Multimediepræsentationer defineres her som streamet video/audio synkroniseret med andre medietyper som f.eks. tekst, grafik, animationer, simuleringer og manipulerbare 2D- og 3D-objekter mm. Det er vores håb, at underviserne med dette redskab vil være med til at forsøge at videreudvikle forelæsningen som form.

\section{Multimediepræsentationer - fra fantasi til virkelighed}

Produktion af interaktive multimediepræsentationer til publicering over Internettet er ikke nogen triviel opgave. Udvikling af den slags læringsressourcer kan i dag kun ske ved brug af en kombination af kommercielle og/eller komplekse forfatterværktøjer (jf. boks 1) og kræver bl.a. megen tid, en indgående viden om web- og streamingteknologier samt adgang til fornødne hard- og softwareressourcer. For at lave vellykkede læringsressourcer af denne type kræves tillige en vis viden om betydningen af narrativitet, dramaturgi og iscenesættelse i en interaktiv kontekst (Fibiger 2003).

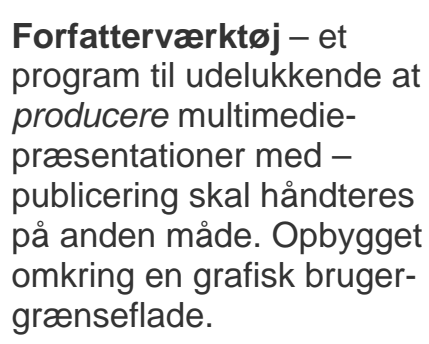
program til udelukkende at producere multimediepræsentationer med publicering skal håndteres på anden måde. Opbygget omkring en grafisk brugergrænseflade.

Boks 1.

Skal undervisere producere præsentationerne på egen hånd, står de således overfor et relativt komplekst problemfelt. Alene på det tekniske område giver processen fra produktion til levering anledning til en mængde indbyrdes afhængige problemstillinger, det kræver stor indsigt at forholde sig til - noget man kan forvisse sig om, ved at kaste et blik på omstående skema (figur 1). Dette betyder i praksis, at brugen af multimediepræsentationer kun vanskeligt lader sig realisere i større målestok i undervisningsmæssig sammenhæng. 


\begin{tabular}{|c|c|}
\hline $\begin{array}{l}\text { Fra produktion } \\
\text { til levering }\end{array}$ & Potentielle problemstillinger [uprioriteret rækkefølge] \\
\hline $\begin{array}{l}\text { Materiale/media } \\
\text { skal samles }\end{array}$ & $\begin{array}{l}\text { Materialer: Hvilke materialer skal anvendes [tekst, grafik, animationer, PPT-, } \\
\text { Tex-, Matlab-filer osv.] og stiller de krav til softwaren hos den studerende? } \\
\text { Formater: Hvilke formater er det mest hensigtsmæssigt at gemme materialerne i } \\
\text { med henblik på den videre proces? }\end{array}$ \\
\hline $\begin{array}{l}\text { Materialerne } \\
\text { skal sættes } \\
\text { sammen til præ- } \\
\text { sentationer } \\
\text { [authoring] }\end{array}$ & $\begin{array}{l}\text { Værktøjer: Hvilke kan bruges til at sammensætte en præsentation? } \\
\text { Platforme: Hvilke platforme kan forfatterværktøjerne bruges på? Skal } \\
\text { underviseren evt. over på en anden platform? } \\
\text { "Cognitive overhead": Hvor nemme er værktøjerne at bruge? } \\
\text { Workflow: Kræves der indsigt i en mængde værktøjer for at opnå det } \\
\text { mål at sammensætte en præsentation? } \\
\text { Output: Hvad er den studerendes muligheder for at afvikle præsentationen til- } \\
\text { fredsstillende? Det afhænger bl.a. af: } \\
\text { Format: Hvilket format er cross-platform? } \\
\text { Codec: Hvilken codec? Hvor godt komprimerer den? Hvor CPU- } \\
\text { krævende er det? } \\
\text { Kvalitet: Hvad er et acceptabelt kompromis mellem kvalitet og hastig- } \\
\text { hed? } \\
\text { Distribueringsmodel: Hvilken distribueringsmodel skal anvendes? } \\
\text { "Objekt"-model: De forskellige mediaelementer sammensættes til en } \\
\text { præsentation i det øjeblik brugeren efterspørger læringsressourcen. } \\
\text { "Projekt"-model: Præsentationen udgøres af én fil [efterfølgende redige- } \\
\text { ring/opdatering kræver at der laves et nyt projekt, som så skal uploades]. } \\
\text { Valget af distribueringsmodel er afgørende for hvilke værktøjer der skal } \\
\text { bruges og har også indflydelse på valget af streamingmodel. }\end{array}$ \\
\hline $\begin{array}{l}\text { Media og/eller } \\
\text { de færdige præ- } \\
\text { sentationer skal } \\
\text { uploades til ser- } \\
\text { ver }\end{array}$ & $\begin{array}{l}\text { Upload: Har underviseren selv mulighed for at gøre det eller skal det gå via en } \\
\text { systemadministrator? Er et evt. upload-interface brugervenligt? Er det nemt for } \\
\text { underviseren at tilgå/fjerne præsentationer/mediaelementer igen? } \\
\text { Lagerplads: Hvor meget kræves der? [Afhænger bl.a. af valg af streamingmodel] } \\
\text { - skal der optimeres til forskellige båndbredder [aktuelt ved HTTP streaming] } \\
\text { kræves stor lagerkapacitet til de forskellige udgaver af samme fil. }\end{array}$ \\
\hline $\begin{array}{l}\text { Præsentationen } \\
\text { skal distribueres }\end{array}$ & $\begin{array}{l}\text { Båndbredde: Hvilken båndbredde har målgruppen? Skal alle uanset båndbredde } \\
\text { kunne se præsentationerne? } \\
\text { Streamingmodel: HTTP eller RTSP? Spørgsmål omkring interaktionsmuligheder } \\
\text { og copyright kan være afgørende for valget. } \\
\text { Copyright: Skal det være tilladt for den studerende at gemme præsentationerne } \\
\text { på deres harddisk? }\end{array}$ \\
\hline $\begin{array}{l}\text { Den studerende } \\
\text { skal se præsenta- } \\
\text { tionen }\end{array}$ & $\begin{array}{l}\text { Softwarekrav: Kræves der særlig browser/plugin/player? } \\
\text { Pris: Gratis eller kommercielt produkt? } \\
\text { Brugervenlighed: Hvor nemt er det at installere komponenten? } \\
\text { Interaktion: Understøttes alle de ønskede funktionaliteter som f.eks. navigation } \\
\text { via TOC rent faktisk [afhænger af streamingmodel]? }\end{array}$ \\
\hline
\end{tabular}

Figur 1. Skemaet angiver et udpluk af de problemstillinger, en underviser risikerer at stå overfor, i tilfcelde af at han/hun selv skal producere multimedieprcesentationer til distribution via Internettet. 
Et besnærende alternativ til situationen, hvor underviseren selv skal finde et svar på alle spørgsmålene, kunne være at lade NIK o.lign. lokale IT-centre stå for udviklingen af multimedieressourcerne - de må jo i hvert fald formodes at have styr på den tekniske side af sagen. Der er imidlertid mindst to forhold, der er af afgørende betydning for dén strategi: 1) fremstillingen af læringsressourcerne kræver en indsigt i det fagområde, der formidles, som centerets medarbejdere ikke kan forventes at have, og 2) et centers personaleressourcer er begrænsede.

Handler det blot om at fremstille en distribueret forelcesning, kan man komme langt med software, der automatisk synkroniserer video- og applikationsevents (et eksempel på et sådant produkt kan ses på http://www.softv.net/Public/presenter2.htm ). En distribueret læringsressource, kræver som Fibiger påpeger, en større grad af hypertekstualisering. Det betyder ikke alene en mere omfattende produktion, men også et krav om en faglig indsigt, og altså at underviserne som minimum skal "sidde med”. I et sådant scenarie er underviserne afhængige af centerets personale, og hvornår det har tid, og vice versa. Afhængigt af volumen af produktioner vil man med andre ord uvægerligt stå overfor et flaskehalsproblem med denne strategi.

Den strategi, vi på NIK har valgt at anlægge, består derfor i at forsøge at flytte så mange arbejdsprocesser som muligt væk fra centret og ud til dem, der har den faglige indsigt, nemlig underviserne. En ideel softwareløsning, der sætter underviserne i stand til selv at udvikle multimedieressourcerne, er i vores opfattelse karakteriseret ved, at den

- ikke kræver specialiserede kompetencer af brugerne

- $\quad$ ikke kræver specialiserede applikationer til produktion og publicering, men blot en browser

- så vidt muligt kan håndtere alle trin i processen fra fremstilling til levering af multimediepræsentationerne

- er en netværks- og serverbaseret løsning, således at det er muligt at opnå en enkel og centralt administreret vedligeholdelse

- tillader genbrug af mediafilerne og letter eventuel rekomprimering af dem

- er platformsuafhængig og baseret på open source / åbne industri standarder for f.eks. meta data

EduMedia er et bud på en sådan softwareløsning.

\section{Systemet EduMedia}

Overordnet set har EduMedia to brugergrænseflader:

1) En portal, hvor alle frit kan browse i eksisterende og tilgængeliggjort materiale.

2) En applikation til upload af media og produktion af multimediepræsentationer. Kræver login.

Bag disse to brugergrænseflader gemmer sig et system, der fysisk består af en række servere og et disk array (et antal diske kombineret i en enkelt enhed for at opnå forøget kapacitet, hastighed og/eller fejltolerance/sikkerhed), jf. omstående illustration (figur 2). I denne sammenhæng er applikationsserveren den mest interessante enhed. Her ligger nemlig applikationen StreamEdit, der er kernen i EduMedia. 


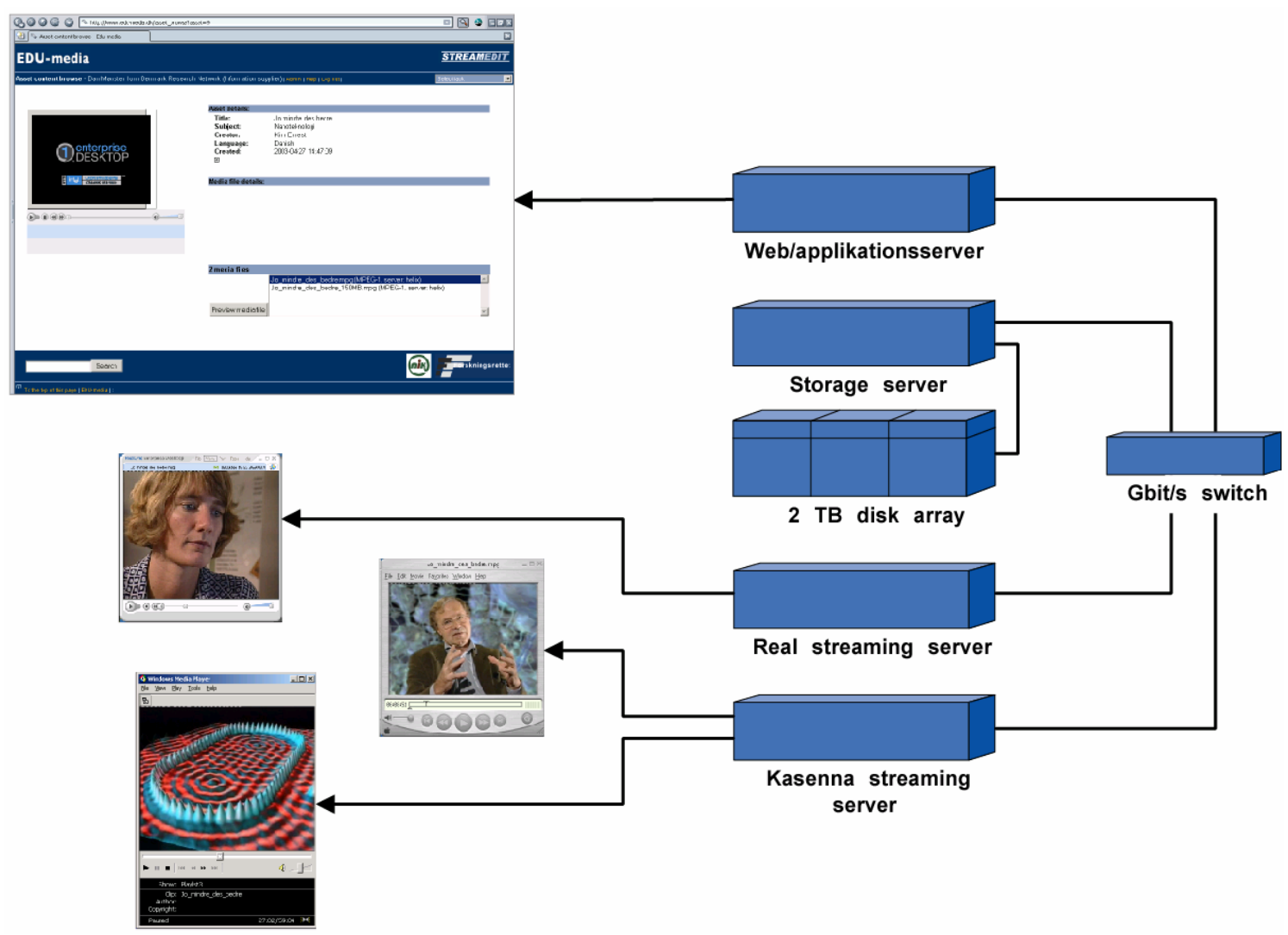

Figur 2. Oversigt over de fysiske enheder, der udgør EduMedia. Maskinellet befinder sig hos Forskningsnettet, dvs. i UNI•C's maskinstue på DTU.

\section{Applikationen StreamEdit}

StreamEdit er en såkaldt webapplikation, dvs. et sessionsorienteret program som via en browser tillader en bruger at logge ind og benytte funktionaliteter på en server. Det betyder, at arbejdet med multimedieressourcerne foregår på applikationsserveren, og at brugeren kun behøver en browser til dette arbejde.

StreamEdit fungerer som et content management system (CMS), der er specielt derved, at det er udbygget til at håndtere alle trin i processen fra fremstilling af multimediepræsentationer til levering af disse over Internettet - jf. tekstboks 2.

StreamEdit består af fem komponenter/moduler til hhv.

1) komprimering af media (via 3. parts løsninger),

2) lagring og administration af mediaelementer,

3) produktion af multimediepræsentationer,

4) brugeradministration, samt

Et CMS gør det muligt via et netværk at behandle, organisere, vedligeholde og distribuere indhold. Grundideen i et CMS er at holde indhold og layout adskilt. Indhold lagres i en database og publiceres uafhængigt af det prædefinerede layout. Dvs. indholdsleverandører kan koncentrere sig om at levere indhold og selv publicere det, uden at det kræver specielle tekniske kompetencer.

Boks 2.

5) distribution af præsentationerne.

Applikationen, der er skrevet i PHP og anvender MySQL som database, er udviklet af det hollandske firma Noterik (http://www.noterik.com - se også http://www.streamedit.com). Pt. er kun de fire af komponenterne implementeret i EduMedia, idet systemet af hensyn til bånd- 
bredde og processor-forbrug ikke er sat op til at håndtere komprimering også - det skal klares lokalt.

De uploadede mediaelementer er selvstændige objekter, der ikke editeres direkte. Præsentationerne består derfor i realiteten kun af referencer til mediaelementerne, dvs. at eksempelvis klipning i video ikke betyder tab af data. Dette princip betyder også, at et givent mediaelement let kan genanvendes i andre præsentationer.

\section{Upload og administration af mediaelementer}

Før man kan fremstille multimediepræsentationerne skal man selvsagt have egnede mediaelementer at lave dem af. Til det brug kan man enten anvende andres materiale, dvs. materiale, der allerede er uploadet, eller man kan uploade sit eget. Endelig kan man også linke til materiale, der befinder sig på eksterne streaming servere.

Når man uploader til EduMedia skal der knyttes metadata til objekterne. F.eks. skal der til et objekt knyttes følgende informationer:

1) titel,

2) hvilken person eller organisation, der er ansvarlig for indholdet af objektet,

3) beskrivelse af indhold,

4) type (video/animation/billede/tekst osv.).

Den store fordel ved metadata er, at de giver informationer om mediaobjekterne udover de rent tekniske (f.eks. varighed, bitrate, opløsning osv.) - informationer der gør det muligt at foretage målrettede søgninger på indholdet af mediaobjekterne - jf. tekstboks 3. For interesserede kan jeg oplyse, at StreamEdits metadata model overholder Dublin Core standarden (http://dublincore.org ).

De uploadede mediaelementer bliver en del af en logisk enhed, en slags "container", kaldet en "asset". En asset indeholder metadata om et eller flere mediaelementer. F.eks. kan en asset indeholde et antal ens videosekvenser med den samme information, men forskellig med hensyn til format og kvalitet. Det er specielt nyttigt, hvis man vil lave en udgave af den samme præsentation til forskellige platforme. En asset er "personlig" i den

Metadata er data om data - dvs. en beskrivelse af de egenskaber, som en ressource har. Metadata forbedrer mulighederne for, at ressourcen genfindes, udvælges og formidles hensigtsmæssigt af søgemaskiner og portaler mv.. Metadata er afgørende, når større mængder information skal organiseres og udgives.

Boks 3. forstand, at kun brugeren, der har oprettet en asset, kan fjerne den igen. Når man har oprettet en eller flere assets kan man gå i gang med at fremstille sin multimediepræsentation.

Assets kan imidlertid gøres til en del af en større logisk enhed kaldet en "collection", eller en samling, der også har sine egne metadata - jf. figur 3. Samlingen kan f.eks. bruges til at holde styr på de assets, der skal bruges til en præsentation, eller man kan lave grupperinger af sit materiale. Derudover har samlinger den fordel, at en bruger kan lade andre brugere tilføje deres assets til hans/hendes samlinger - noget der er nyttigt i gruppearbejde. F.eks. kan en underviser oprette en samling, som studerende i forbindelse med opgavebesvarelser kan bruge som udgangspunkt for egne multimediepræsentationer. På den måde giver EduMedia nye pædagogiske og didaktiske muligheder.

Omstående screen dump (figur 4) viser brugerens kontrolpanel.

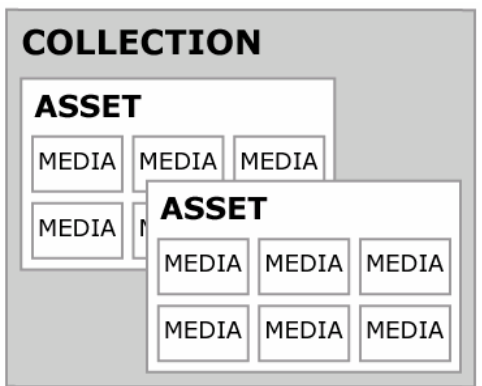

Figur 3. Illustration af hierakiet mediaelement, "asset", "collection". 


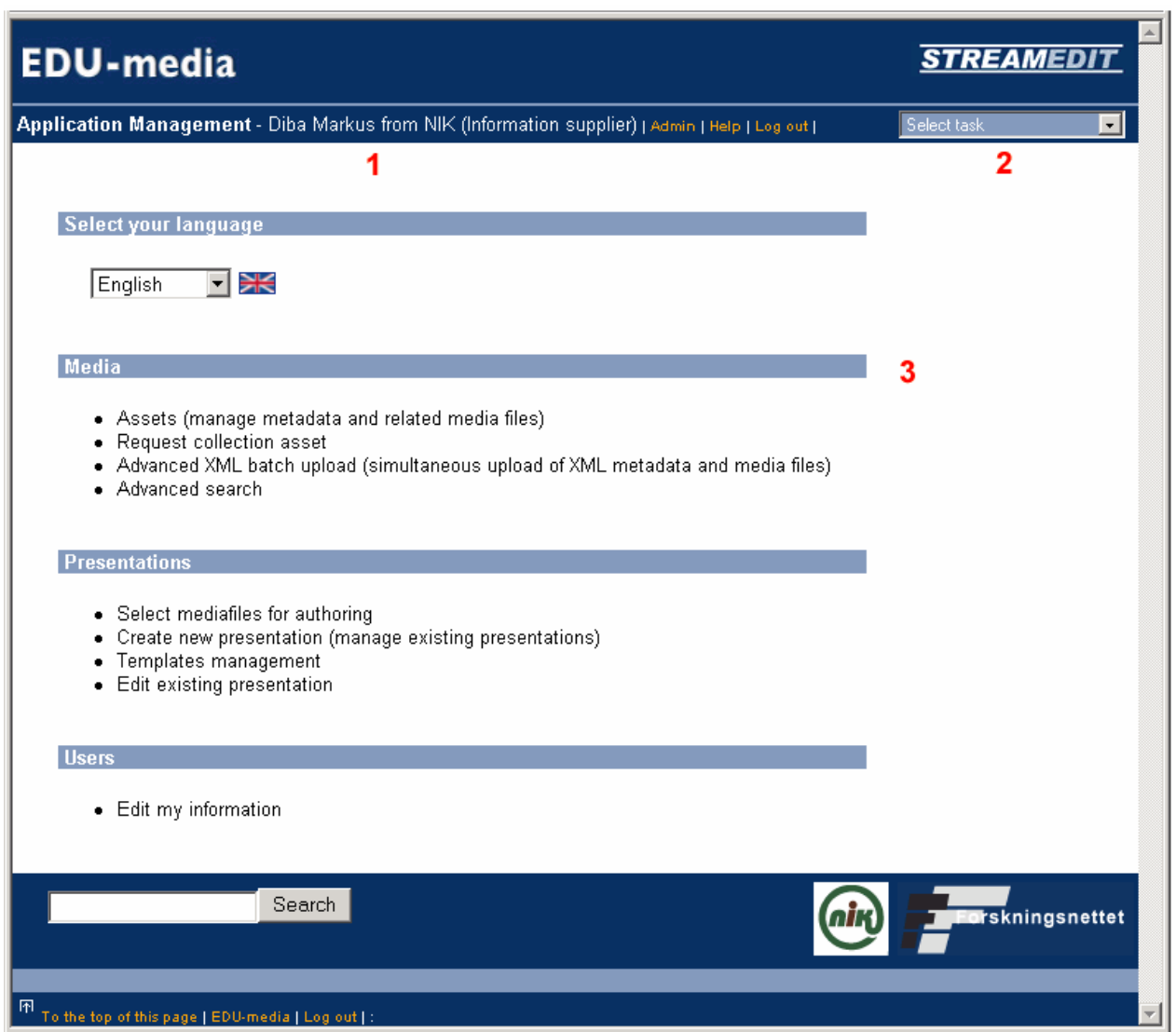

Figur 4. Brugerens kontrolpanel i EduMedia med 1) brugeroplysninger, 2) kvikmenu (short cut menu) og 3) hovedmenu.

\section{Produktion af multimediepræsentationer}

Også den enkelte præsentation kan opfattes som en ”container”, der rummer alle relevante informationer i forbindelse med en multimediepræsentation, f.eks. præsentationens titel, info på underviser, rettigheder mv., samt referencer til mediaelementerne.

Selve fremstillingen af multimediepræsentationerne forgår via en brugergrænseflade, der er udformet som en "foldud-menu" med previewfunktion jf. figur 5.

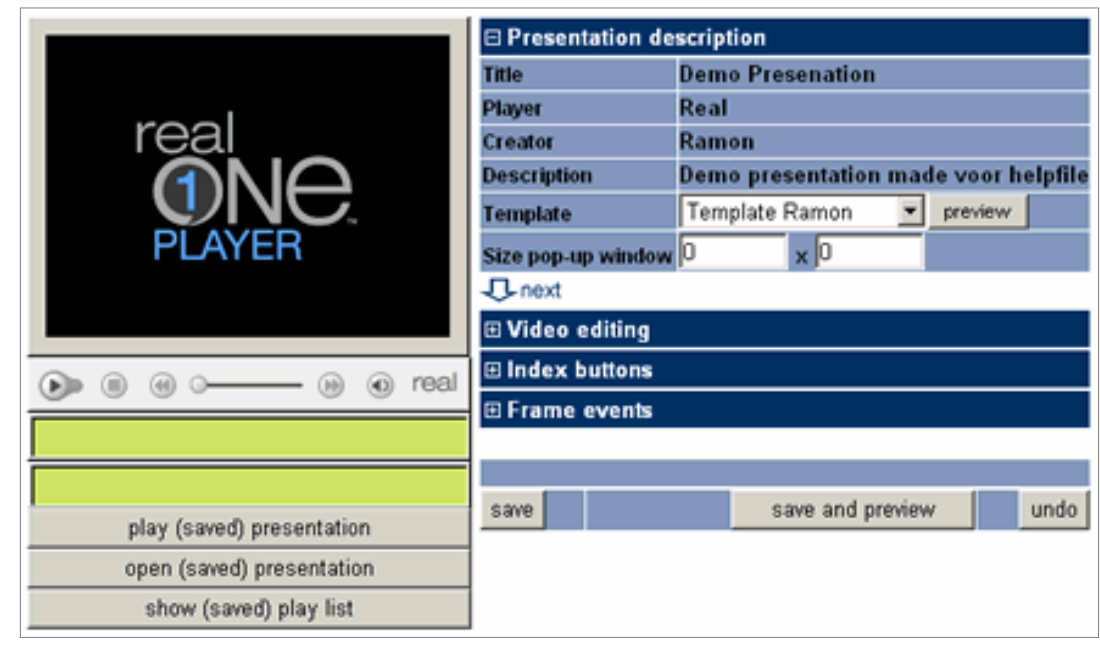

Figur 5. EduMedias værktøj til fremstilling af multimedieprcesentationer. Takket være at det er organiseret som en 'foldudmenu' kan alle funktioner være på én side. 
I menuen kan man bl.a. vælge blandt en række ”templates”, prædefinerede designs, der udelukkende dikterer, hvordan elementer, såsom indholdsfortegnelse, videovindue o.lign. sættes op/organiseres i den endelige præsentation. Det kræver således implementering på administratorniveau, hvis en organisation ønsker at anvende en gennemgående design-linie med eget logo, egen særlige ”firmafarve” oa., der kan understøtte en branding af organisationen.

\section{Distribution}

Ligesom fremstillingen sker også publiceringen af de færdige præsentationer via en browser. Publiceringen foregår efter en "on-request”-model, dvs. en given multimediepræsentation vil altid først blive genereret ud fra referencerne til elementerne i det øjeblik den efterspørges. Dermed vil præsentationerne altid afspejle seneste ændringer - det vil altid være de seneste ”versioner", der er tilgængelige.

StreamEdit understøtter alle betydende streaming klienter, som Real Player, Windows Media Player, QuickTime Player og Kasenna Broadband Player med den modifikation, at den underliggende streaming arkitektur er af konsekvens for, hvilke StreamEdit funktioner, der kan anvendes. Præsentationerne kan afvikles i Internet Explorer 5 ${ }^{+}$, seneste versioner af Mozilla og Netscape - simple præsentationer kan dog afvikles i browsere af ældre dato. Afviklingen af præsentationerne er stadig bedst på Windows, men Noterik arbejder på at få en tilsvarende god afvikling på Mac og Unix. Principielt er det også muligt at distribuere multimediepræsentationerne på håndholdte enheder. Denne mulighed har vi dog valgt ikke at implementere i denne omgang, selvom det bestemt vil være en relevant distributionskanal på sigt.

Der streames udelukkende i "realtid”, dvs. via RTSP (RealTime Streaming Protocol), hvilket bl.a. har den konsekvens, at videosekvenser ikke kan downloades på slutbrugerens harddisk. Denne protokol er primært valgt for så vidt muligt at forebygge copyright problemer. Træerne vokser dog ikke ind i himlen, for der findes et utal af små uautoriserede applikationer til at "grabbe" en videostrøm med.

Fra EduMedia kan der streames både til lave og høje båndbredder, men afviklingen afhænger naturligvis af mængden af trafik på netværket, og hvor mange forespørgsler streaming serverne skal håndtere samtidigt. Der er derfor i princippet ingen krav til, hvor meget eller lidt man komprimerer sit materiale, men man gør naturligvis klogt i at tage højde for slutbrugernes muligheder for at afvikle det.

\section{Administration}

StreamEdit opererer med en stringent model for brugerroller og -rettigheder. I EduMedia er denne model implementeret således, at der er fire typer brugere af systemet:

\section{End users:}

Er alle, der anvender portalen til at søge i, og som slutteligt anvender multimediepræsentationerne som læringsressourcer, altså typisk studerende. Denne brugerrolle giver kun adgang til at se materiale, der er gjort tilgængeligt via portalen.

\section{Information Supplier:}

Denne brugertype har de laveste administrative privilegier i systemet. "Information suppliers" har udelukkende ret til at uploade materiale, fremstille multimediepræsentationer og administrere egne oplysninger og assets.

\section{Section Administrator:}

Denne bruger har administratorrettigheder i forhold til sin egen organisation, også kaldet en "section”. En organisation kunne f.eks. være et universitet. Section administrator kan oprette 
brugere, dvs. information suppliers, for sin organisation og har i et vist omfang adgang til at trække statistiske oplysninger ud af systemet.

\section{Super Administrator:}

Denne rolle giver adgang til administration af alle niveauer i systemet og alle data. Super administrator kan oprette organisationer.

\section{Workflow}

Som en opsummering på den noget teknisk prægende gennemgang af EduMedia og brugen af systemet, kan nedenstående illustration (figur 6) forhåbentligt anskueliggøre arbejdsgangen.

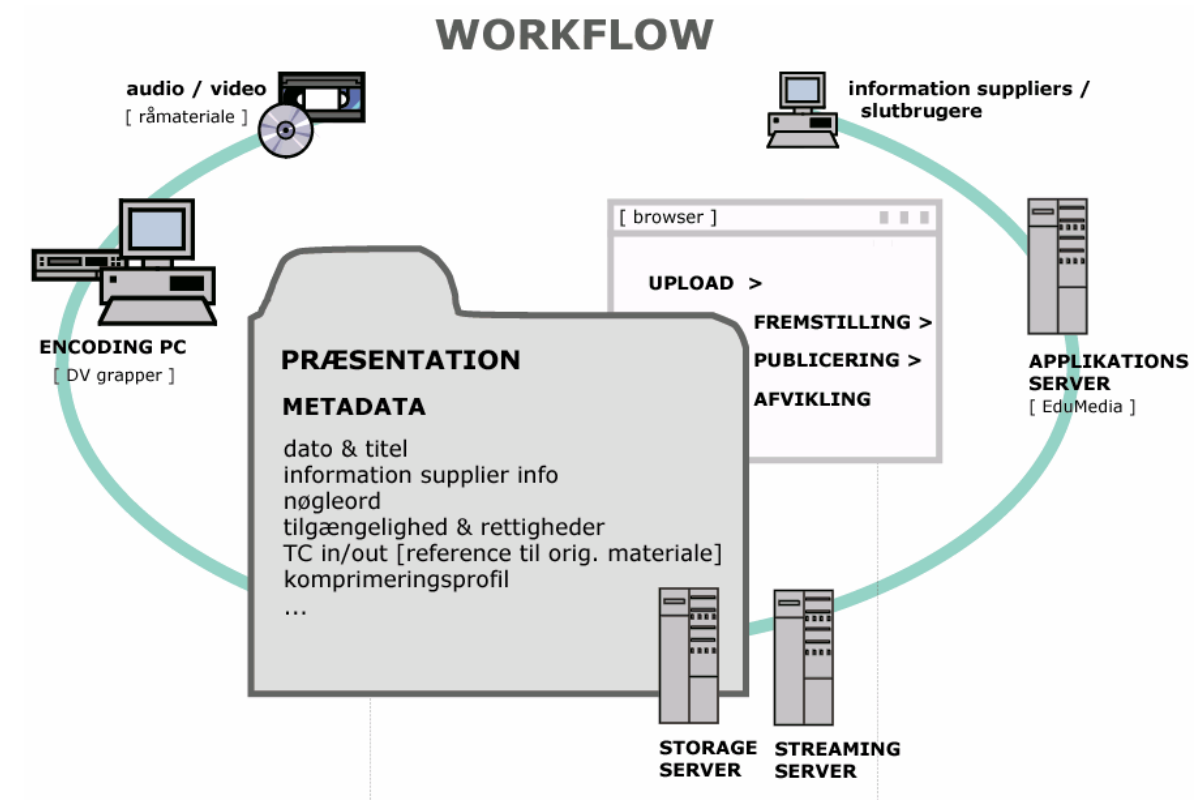

Figur 6. Produktionsgangen fra komprimering (encoding) og upload af audio-/video materiale til produktion og publicering af prcsentationer via EduMedias browserbaserede forfattervcrktøj. Komprimering af media er dog ikke omfattet af EduMedias nuvcrende funktionaliteter, men skal foretages lokalt.

Som nævnt er systemet ikke sat op til at håndtere komprimering - det skal klares lokalt. Dette kræver adgang til hard- og softwareressourcer, indsigt i at bruge dem og ikke mindst tid. Komprimering kan være en kunstart i sig selv, idet der er mange indbyrdes afhængige parametre, der er af betydning for et godt resultat. Derfor er det formentligt urealistisk at opnå en betydelig volumen af multimediepræsentationer, hvis ikke komprimeringen af audio/videomaterialet indtænkes i et workflow, hvor et lokalt IT-center tager sig af dén del af processen og eventuelt også er ansvarlig for at uploade det komprimerede materiale til systemet.

\section{Projektet EduMedia}

I foråret 2002 startede undertegnede en uformel research, der havde til formål at afdække tekniske problemstillinger i forbindelse med platformuafhængig produktion og levering af multimediepræsentationer over Internettet. Sidst på året var projektet modnet så meget, at NIK besluttede at arbejde på at finde en løsningsmodel til underviserne ved det naturvidenskabelige fakultet. Spørgsmålet var blot hvordan den skulle se ud.

Diverse kommercielle forfatterværktøjer som f.eks. Macromedia Authorware blev afprøvet, men selvom de måske opfyldte kravene til et pædagogisk og brugervenligt udviklingsmiljø til fremstilling af multimediapræsentationer, så havde de andre ulemper, vi ikke kunne se bort 
fra. F.eks. at præsentationerne kun kunne afvikles på en delmængde af de platforme, der anvendes på fakultetet, og/eller de opererede med en "projekt"-model. Præsentationer lavet efter dette koncept er "pakket” i én fil, og man kan f.eks. ikke rekomprimere videosekvenser uden at skulle lave et helt nyt projekt, som så skal uploades.

På samme måde blev også diverse freeware-løsninger vejet og fundet for lette. En af de mest lovende kandidater var Real Networks SMIL-baserede RealProducer. Dels fordi den er baseret på en åben standard beskrevet af World Wide Web Consortium (http://www.w3c.org), og dels fordi den opererer med en "objektorienteret” tilgang til produktionen af præsentationer, der netop muliggør eventuel senere opdatering af mediaelementerne. RealProducer blev imidlertid vraget, fordi streaming udelukkende i Real-format simpelthen er for dyrt, så snart man når en vis volumen i antal streams. Og sådan kan man blive ved.

Selvom vi havde fundet det ultimative forfatterværktøj, ville vi dog stadig skulle udvikle et system til at håndtere, organisere, vedligeholde og distribuere større datamængder. Vi begyndte derfor at se på diverse content management systemer, fordi et CMS netop har potentiale til at håndtere hele processen fra produktion til publicering. Der findes imidlertid ikke mange content management systemer, der som StreamEdit er udbygget med et værktøj til at producere multimediepræsentationer.

\section{Samarbejde mellem NIK og Forskningsnettet}

Ved årskiftet 2002-2003 indgik NIK på vegne af Københavns Universitet (KU) så kontrakt med Noterik omkring afprøvning af deres CMS StreamEdit fuldt implementeret lokalt i seks måneder. Kontrakten var dog formuleret således, at prøvetiden først kunne startes den dag, Noterik havde et produkt, der var fuldt funktionsdygtigt på samtlige de platforme, fakultetet anvender. Det er et krav vi har valgt at slække lidt på, da det er en situation vi forventer, bliver løst i den nærmeste fremtid.

På NIK følte vi, at vi stod med et projekt, der kunne være af mere generel interesse end blot for undervisere ved KUs naturvidenskabelige fakultet. Kort forinden kontraktindgåelsen kontaktede vi derfor Forskningsnettet med henblik på at indlede et samarbejde omkring EduMedia For de, der ikke skulle vide det, kan jeg som en service oplyse, at Forskningsnettet leverer højhastigheds-Internet til samtlige landets universiteter samt en række andre offentlige institutioner og forskningsbaserede virksomheder i Danmark - i dag er ca. 110 institutioner tilsluttet. Forskningsnettet så velvilligt på sagen, og samarbejdet var en realitet. EduMediaprojektet ledes således af NIK, men udføres i samarbejde med Forskningsnettet og Noterik og med assistance fra mediekonsulent Kim Ernest, Ernest Film.

\section{Status}

Pr. 1. januar 2004 er EduMedia gået ind i en pilotprojektfase, der skal danne basis for beslutningen om, i hvilken udstrækning Københavns Universitet og/eller Forskningsnettet ønsker at støtte op omkring et system til produktion og distribuering af interaktive multimediepræsentationer over Internettet. Det er selvsagt en afgørende fase, hvor alle erfaringer med systemet er vigtige. Derfor vil jeg opfordre dig, kære læser, til at klikke ind på www.edumedia.dk, blive oprettet på systemet og se hvad det har at byde på. Systemet er som anført i en pilotfase, og vi er opmærksomme på, at nogle videoklip ikke vil virke bl. a. p. gr.a. sikkerhedsindstillinger i firewalls både på universiteter og via ADSL forbindelser. Al konstruktiv kritik er velkommen, så husk at give os din feedback.

Internt på NIK er vi pt. i gang med at teste EduMedias grænseflade og interaktionsdesign med henblik på at afdække uhensigtsmæssigheder og fremkomme med forslag til designændringer.

For at inspirere eventuelt interesserede til at bruge EduMedia, vil jeg afslutte med at give en række eksempler på, hvordan multimediepræsentationer kan bruges. 


\section{Brugsscenarier}

Multimediepræsentationer kan bruges i mange sammenhænge. Specielt begivenheder eller aktiviteter, der er fastholdt med videooptagelser, eller hvor videooptagelse kunne laves, er selvfølgelig oplagte at bruge som udgangspunkt. Men også uden video kan der laves læringsressourcer, der tilgodeser behovet for selv at bestemme tid, sted og tempo for læringen.

\section{Undervisning:}

Udover at undervisere kan udvikle regulære distribuerede læringsressourcer, der kan bruges til de studerendes selvstændige arbejde med et stof, kan de selvfølgelig også distribuere egne forelæsninger som multimediepræsentationer til de studerende, der ikke kan være til stede. I tilstedeværelsesundervisning kan multimediepræsentationer f.eks. bruges som øvelsesvejledninger, som "case studies” eller til at diskutere oplægget fra sidste års berømte gæsteforelæser. Endelig kan underviseren bruge EduMedia som platform for gruppesamarbejde, hvor det er de studerende, der skal "verbalisere" deres viden ved at producere præsentationer, der formidler et stof, et forskningsresultat eller noget helt tredje.

\section{Forskning:}

Forskningsresultater kan formidles via multimediepræsentationer på en både seriøs og engagerende måde, i og med at man har lejlighed til f.eks. at fremvise og gennemgå forsøgsopstillinger "live” og demonstrere forsøg samtidigt med, at man kan linke til relevant dokumentation og uddybende information.

\section{Administrative informationer:}

Multimediepræsentationer kan bruges til at oplære medarbejdere i administrative funktioner eller gennemgå sikkerhedsforskrifter i laboratorier m.m. Her kan de fungere som et alternativ/supplement til skriftlige instrukser og sidemandsoplæring.

\section{Generel Information og promovering:}

Sidst men ikke mindst kan multimediepræsentationer bruges til at formidle generelle, praktiske informationer om universitetet, det enkelte institut eller afdeling eller aktiviteter.

\section{Litteratur}

Bargeon, D., Grudin, J., Gupta, A., Sanocki, E., Li, F., and LeeTiernan, S. 2002. "Asynchronous Collaboration Around Multimedia Applied to On-Demand Education." Journal of Management Information Systems, 18, 4: 117-145.

Collis, Betty, \& Jeff Moonen. Flexible Learning in a FlexibleWorld. Kogan Page, 2001.

Fibiger, Bo. "Streaming video - grundlæggende genrer i læringsomgivelser." Tidsskrift for universiteternes efter- og videreuddannelse (2003): 108-117.

Haga, Hirohide. "Combining video and bulleting board systems in distance education systems." Internet and Higher Education, 5 (2002): 119-129.

Hornbæk, Kasper, \& Diba Engberg, \& Jørgen Gomme. "Video Lectures: HCI and e-learning problems", in Workshop on Human-computer interaction and E-learning, NORDICHI 2002. http://www.diku.dk/ kash/publications.htm

\section{Referencer/yderligere information}

CMS: http://www.ucsf.edu/itgovernance/subcommittees/websub/content-mgt.pdf

EduMedia: http://www.edumedia.dk

Forskningsnettet: http://www.forskningsnettet.dk 